\title{
PENGARUH KECERDASAN EMOSIONAL, DAN SELF EFFICACY TERHADAP KINERJA GURU MATEMATIKA
}

\author{
Susnaini Julita ${ }^{1}$, Dewi Herawaty ${ }^{2}$, Sandra Alfi Gusri ${ }^{3}$ \\ ${ }^{1}$ SMP Negeri 2 Kota Bengkulu \\ Jalan Cendana, Padang Jati, Bengkulu, Indonesia \\ ${ }^{1,2,3}$ Prodi Pendidikan Matematika FKIP, Universitas Bengkulu \\ Jalan WR Supratman, Kandang limun, Muara Bangka Hulu, Bengkulu, Indonesia \\ e-mail: ${ }^{1}$ susnainijulita@gmail.com;
}

\begin{abstract}
Abstrak
Penelitian ini bertujuan untuk memahami hubungan antara kecerdasan emosional self efficacy dan kinerja guru matematika. Metode ini dilakukan oleh penelitian survei. Sampel penelitian ini adalah 80 guru guru sekolah menengah atas sebagai kota Bengkulu. Sampel dipilih dengan sederhana sampling acak. Data dikumpulkan melalui teknik kuesioner Skala Likert. Analisis statistik untuk data, kami menerapkan analisis jalur. Hasil penelitian ini adalah 1) ada pengaruh langsung kecerdasan emosional terhadap kinerja guru matematika, 2) ada pengaruh langsung self efficacy terhadap kinerja guru matematika, 3) ada pengaruh langsung dari kecerdasan emosional terhadap self efficacy.
\end{abstract}

Kata Kunci: pekerjaan kinerja guru matematika, Emotional Intelligence, self efficacy

\section{THE EFFECT OF EMOTIONAL INTELLIGENCE, AND SELF EFFICACY ON JOB PERFORMANCE OF MATHEMATICS TEACHER}

\begin{abstract}
The research was purpose to understand the relationship between emotional intelligence self-efficacy and job performance math teacher. The method was conducted by survey research. The research sample were 80 teachers of teachers on the junior high schools as Kota Bengkulu. The sample was selected by simple random sampling. The data was collected through a Likert scale questionnaire technique. The statistical analysis for the data, we were applied path analysis. The results of this study were 1) there is direct effect of emotional intelligence towards job performance math teacher, 2) there is direct effect of self-efficacy towards job performance math teacher, 3) there is direct effect of emotional Intelligence towards selfefficacy.
\end{abstract}

Keywords: job performance math teacher, emotional intelligence, self efficacy

\section{Pendahuluan}

Guru adalah pendidik profesional yang mendidik, mengajarkan suatu ilmu, membimbing, melatih, memberikan penilaian, serta melakukan evaluasi kepada peserta didik. Mereka memiliki kompetensi untuk mendidik siswa (Herawaty, 2015b). Karena itu, guru harus memiliki self efficacy, kecerdasan emosional, dan motivasi dalam kinerjanya (Herawaty, 2016). Menurut Abdolvahabi, Bagheri, \& Kioumarsi (2012), efektivitas guru yang tinggi dalam membantu siswa, meningkatkan empati mereka. Oleh karena itu, dengan mendapatkan lebih banyak pengalaman, perasaan lebih self efficacy dalam membantu orang lain dapat tercapai. Bandura (1994) menyatakan bahwa self efficacy sebagai "keyakinan masyarakat tentang kemampuan mereka untuk menghasilkan tingkat kinerja yang ditunjuk yang mempengaruhi kegiatan yang mempengaruhi kehidupan mereka" (Ream, 2010). Juga, kecerdasan emosional adalah seperangkat kemampuan non-kognitif yang meningkatkan kemampuan seseorang untuk mengatasi tuntutan lingkungan dan tekanan yang dihasilkan (Hashemi, Kimiaie, \& Hashemizadeh, 2014).

Menurut Hashemi, et al, (2014), self efficacy memainkan peran penting dalam menghadapi masalah kehidupan individu. Hasil 
penelitian Herawaty, (2016), dan Afifi, (2016) menunjukkan bahwa self-efficacy berkorelasi positif dengan kecerdasan emosional. Menurut Hashemi et al., (2014), self efficacy adalah memastikan kemampuan guru untuk mengendalikan pikiran, perasaan dan kegiatan dan karena itu efektif dalam kinerja aktual individu, emosi dan pemilihan orang, dan akhirnya jumlah usaha yang dihabiskan seseorang pada kegiatan pendidikan. Dengan demikian kecerdasan emosional dan self efficacy guru sangat penting untuk mencapai kinerja yang baik.

Menurut Herawaty (2016), self efficacy yang dimiliki oleh guru, dapat mengurangi tingkat kecemasan yang berlebihan dalam menghadapi kegiatan pemenuhan beban kerja sebagai bentuk kinerja guru matematika. Self efficacy akan meningkatkan keinginan yang kuat dari guru untuk melaksanakan kegiatannya sebagai guru profesional. Motivasi yang kuat ini adalah representasi motivasi diri guru. Oleh karena itu, guru diharapkan mampu mencapai standar kualitas sumber daya manusia sebagai seorang profesional. Guru yang memiliki motivasi kerja tinggi akan meningkatkan keinginan mereka untuk selalu melaksanakan kegiatan yang mendukung kinerja mereka (Herawaty, 2015b). Ini berarti motivasi kerja guru harus selalu ditingkatkan untuk mendorong peningkatan kinerjanya. Motivasi kerja guru merupakan faktor penting dalam meningkatkan kinerja, karena itu sebagai pendorong utama setiap guru melaksanakan tugas profesionalnya sesuai dengan peraturan yang berlaku.

Menurut Hashemi et al. (2014), ada korelasi yang signifikan antara kecerdasan emosional dan kepemimpinan yang efektif, ada korelasi yang signifikan antara self efficacy dan kepemimpinan yang efektif, dan terakhir, ada korelasi yang signifikan antara kecerdasan emosional dan self efficacy. Selain itu, menurut hasil penelitian Herawaty (2016), bahwa kecerdasan emosional, guru partisipasi dalam forum ilmiah, self efficacy dan motivasi mempengaruhi secara langsung terhadap kinerja guru matematika.

Deskripsi di atas menunjukkan bahwa kecerdasan emosional dan self efficacy sebagai atribut memainkan peran dalam kinerja guru. Oleh karena itu, kami didorong untuk meneliti dan menulis tentang pengaruh kecerdasan emosional dan self efficacy terhadap kinerja guru.

\section{Metode Penelitian}

Metode penelitian adalah survei. Populasinya adalah guru sekolah menengah atas di Kota Bengkulu. Sampel penelitian dipilih dengan teknik sampling acak sederhana sebanyak 15\% dari total populasi terjangkau (534 guru). Dengan demikian, ukuran sampel dari studi ini adalah 80 orang. Instrumen penelitian adalah bentuk kuesioner. Instrumen ini disusun mengacu pada pada definisi operasional dan kisi-kisi masing-masing variabel. Setiap item kuesioner dilengkapi dengan lima pilihan alternatif. Analisis Pengujian hipotesis menggunakan statistik inferensial, yakni analisis jalur (path analysis), yang diawali dengan perkiraan kesalahan uji normalistas.

\section{Hasil dan Pembahasan}

\subsection{Analisis Deskriptif}

Berdasarkan perhitungan statistika deskriptif, skor kinerja Guru SMP di Bengkulu adalah nilai terendah 207 dan mendapat nilai tertinggi 260. Berdasarkan diagram jalur substruktur, maka berikut ini dapat disajikan hasil pengujian hipotesis:

\section{a. hipotesis: Emotional Intelligence berpengaruh langsung positif terhadap kinerja guru matematika}

Pengujian pada pengaruh Emotional Intelligence $\left(\mathrm{X}_{1}\right)$ dari kinerja guru $(\mathrm{Y})$ diuji dengan menggunakan hipotesis pasangan sebagai berikut:

$$
\begin{aligned}
& \mathrm{H}_{0}: \beta_{\mathrm{y} 1} \leq 0 \\
& \mathrm{H}_{1:} \beta_{\mathrm{y} 1}>0
\end{aligned}
$$

Berdasarkan perhitungan yang diperoleh koefisien jalur $\mathrm{X}_{1}$ ke $\mathrm{Y} \quad\left(\boldsymbol{\rho}_{\mathrm{y} 1}\right)$ sebesar 0,103 ; dengan $\mathrm{t}=3,215, \mathrm{t}_{\text {tabel }}(\alpha=0,05, \mathrm{DF}=75)=$

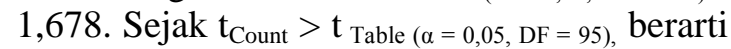
bahwa menolak Ho dan menerima $\mathrm{H}_{1}$. Dapat disimpulkan bahwa koefisien jalur yang signifikan, yang berarti bahwa kecerdasan emosional berpengaruh langsung positif terhadap kinerja guru, dengan besar pengaruh $15,45 \%$.

b. hipotesis: Self efficacy (X2) berpengaruh langsung positif terhadap kinerja guru matematika (Y)

Pengujian pada pengaruh efektivitas diri $\left(\mathrm{X}_{2}\right)$ terhadap kinerja guru (Y) diuji dengan menggunakan hipotesis pasangan sebagai berikut:

$$
\mathrm{H}_{0:} \beta_{\mathrm{Y} 2} \leq 0
$$




$$
\mathrm{H}_{1:} \beta_{\mathrm{Y} 3}>0
$$

Berdasarkan perhitungan yang diperoleh koefisien jalur $\mathrm{X}_{3}$ untuk $\left.\mathrm{Y} \quad \mathbf{(}_{\mathbf{Y} \mathbf{3}}\right)$ sebesar 0,143 ; dengan $\mathrm{t}=3,753, \mathrm{t}_{\text {tabel }}(\alpha=0,05, \mathrm{DF}=75)=$ 1,678. Sejak $\left.t_{\text {Count }}>t_{\text {Table }(\alpha=0,05, D F}=75\right)$, berarti bahwa menolak Ho dan menerima $\mathrm{H}_{1}$. Dapat disimpulkan bahwa koefisien jalur yang signifikan, yang berarti bahwa self efficacy berpengaruh langsung positif terhadap kinerja guru, dengan besar pengaruh 10,57\%.

\section{c. hipotesis: Kecerdasan emosional berpengaruh langsung positif terhadap guru matematika Self efficacy}

Pengujian pada pengaruh kecerdasan emosional $\left(\mathrm{X}_{1}\right)$ atas self efficacy $\left(\mathrm{x}_{2}\right)$ diuji dengan menggunakan hipotesis pasangan sebagai berikut:

$$
\begin{aligned}
& \mathrm{H}_{0:} \beta_{21} \leq 0 \\
& \mathrm{H}_{1:} \beta_{21}>0
\end{aligned}
$$

Berdasarkan perhitungan yang diperoleh koefisien jalur $\mathrm{X}_{1}$ hingga $\mathrm{X}_{2}\left(\boldsymbol{\rho}_{21}\right)$ sebesar 0,252 ; dengan $\mathrm{t}=4,325, \mathrm{t}_{\text {tabel }}(\alpha=0,05, \mathrm{DF}=75)=$ 1,678. Sejak $\left.t_{\text {Count }}>t_{\text {Table }(\alpha=0,05, D F}=75\right)$, berarti bahwa menolak Ho dan menerima $\mathrm{H}_{1}$. Dapat disimpulkan bahwa koefisien jalur yang signifikan, yang berarti bahwa kecerdasan emosional guru berpengaruh langsung positif terhadap self efficacy, dengan besar pengaruh $9,85 \%$.

Hasil analisis data menunjukkan bahwa kecerdasan emosional memiliki pengaruh positif langsung terhadap kinerja guru. Menurut (Herawaty, 2016). Pernyataan yang memperkuat teori bahwa kecerdasan emosional (kesadaran diri, manajemen diri, motivasi, pemahaman, dan keterampilan sosial) secara signifikan mempengaruhi efisiensi kerja dan keberhasilan operasional. Herawaty, (2015a), lebih lanjut menjelaskan bahwa peningkatan kinerja guru matematika dipengaruhi secara positif oleh peningkatan kecerdasan emosional. Dengan demikian kecerdasan emosional untuk menjadi guru yang tinggi akan mengarah pada realisasi kinerja tinggi guru. Kecerdasan emosional secara signifikan mempengaruhi kepuasan dan kinerja kerja (Supriyanto \& Troena, 2012; Susi Hendriani, Yulia Efni, 2013; Wibowo, 2015).

Temuan kedua penelitian ini adalah Selfefficacy memiliki pengaruh langsung positif terhadap kinerja guru. Hal ini sesuai dengan temuan Herawaty (2016) bahwa semakin tinggi self efficacy seseorang, semakin baik kegiatan yang dilakukan dalam berbagai tugas dan tanggung jawab. Menurut Herawaty, (2015a), peningkatan kinerja guru secara langsung dipengaruhi secara positif oleh peningkatan kepercayaan guru matematika. Dengan demikian, efektivitas guru yang tinggi akan berdampak positif pada peningkatan kinerja guru dapat diwujudkan dalam bentuk kinerja tinggi.

Hasil pengujian hipotesis ke-3 menunjukkan bahwa kecerdasan emosional memiliki dampak positif secara langsung pada self efficacy guru. Hal ini menunjukkan bahwa kecerdasan emosional merupakan aspek atau variabel penting yang perlu diupayakan peningkatannya. Kecerdasan emosional guru yang tinggi akan meningkatkan self efficacy guru. Dengan demikian, upaya peningkatan kecerdasan emosional guru perlu dilakukan, misalnya melalui program pelatihan, program pembinaan guru, dsb. Menurut Herawati, 2015a, 2016), program pelatihan untuk meningkatkan kecerdasan emosional akan membuat kontribusi yang berharga, terutama kepercayaan pada kemampuan guru muda, anak laki, dan guru yang memiliki status lebih rendah.

\section{Kesimpulan}

Simpulan penelitian ini adalah (1) kecerdasan emosional berpengaruh langsung positif terhadap kinerja guru, dengan besar pengaruh $15,45 \%$; (2) self efficacy berpengaruh langsung positif terhadap kinerja guru, dengan besar pengaruh 10,57\%, dan (3) kecerdasan emosional guru berpengaruh langsung positif terhadap self efficacy, dengan besar pengaruh $9,85 \%$.

Upaya peningkatan kecerdasan emosional guru misalnya melalui pelatihan guru perlu diperhatikan, karena akan memberikan kontribusi langsung terhadap peningkatan self efficacy guru dan kinerja guru.

\section{Daftar Pustaka}

Abdolvahabi, Z., Bagheri, S., \& Kioumarsi, F. (2012). Relationship between Emotional Intelligence and Self-efficacy in Research among Tehran Physical Education Teachers Department of Physical Education and Sport Science, Shahr-eGods Branch, Islamic Azad. European Journal of Experimental Biology, 2(5), 1778-1784.

Afifi, M. (2016). Emotional Intelligence, SelfEfficacy and Academic Performance among University Students. IOSR Journal of Nursing 
and Health Science (IOSR-JNHS), 5(3), 74-81. https://doi.org/10.9790/1959-0503027481

Hashemi, S. A., Kimiaie, A., \& Hashemizadeh, S. M. (2014). Title: The relationship between emotional intelligence and self-efficacy and academic performance of students. World Essays Journal, 1(2), 65-70.

Herawaty, D. (2015a). Hubungan Kecerdasan Emosional Dengan Partisipasi Guru Matematika Dalam Forum Ilmiah. Jurnal Math Educator Nusantara, 1(1), 21-28.

Herawaty, D. (2015b). Profil Kompetensi Guru Matematika Jenjang SMP di Kota Bengkulu. Jurnal Penelitian Pendidikan Matematika Dan Sains, 22(1), 77-83.

Herawaty, D. (2016). Pengaruh Kecerdasan Emosional, Partisipasi Guru dalam Forum Ilmiah, Self efficacy, dan Motivasi Kerja terhadap Kinerja Guru Matematika. Jurnal Review Pembelajaran Matematika (JRPM), 1(1), 71-85. Retrieved from http://jrpm.uinsby.ac.id

Ream, K. S. (2010). The Relationship of Emotional Intelligence and Self-Efficacy of First and Second Year Principals. Dissertation at the University of Missouri-Columbia, (December).

Supriyanto, A., \& Troena, E. (2012). Pengaruh Kecerdasan Emosional dan Kecerdasan Spiritual terhadap Kepemimpinan Transformasional, Kepuasan Kerja dan Kinerja Manajer (Studi di Bank Syariah Kota Malang). Jurnal Aplikasi Manajemen, 10(4), 693-709. Retrieved from http://jurnaljam.ub.ac.id/index.php/jam/article/v iewFile/455/493

Susi Hendriani, Yulia Efni, R. (2013). Kecerdasan emosional, komunikasi, komitmen, dan kinerja pegawai. Jurnal Ilmu Komunikasi, 2(3), 57-66.

Wibowo, C. T. (2015). Analisis pengaruh kecerdasan emosional (EQ) dan kecerdasan spiritual (SQ) terhadap kinerja karyawan. Jurnal Bisnis Dan Manajemen, 15(1), 1-16. 